\title{
RAZVIJANJE POTENCIALOV ŠTUDENTOV Z DISLEKSIJO
}

Globalna finančna kriza je močno prizadela tudi Slovenijo, zato bi moralo vodstvo države spodbuditi širše okolje k iskanju virov, ki nam bodo pomagali najti pot iz težav. Med premalo izkoriščenimi strokovnimi viri z veliko kreativnimi idejami, ki vidijo probleme in tudi rešitve zanje sirše, so tudi inovatorji, ki imajo disleksijo. Številni študenti z disleksijo, ki so nadarjeni na nekem področju, danes ne morejo uspešno kompenzirati svojih primanjkljajev in končati študija.

Ocenjujejo, da je med odraslimi prebivalci okrog pet odstotkov takih z disleksijo. Najpogosteje jih opisujejo kot zelo heterogeno skupino oseb, ki imajo nevrološko pogojene motnje usvajanja in avtomatizacije veščin branja, pisanja ter računanja ob povprečnih do nadpovprečnih intelektualnih sposobnostih.

Osebe z disleksijo so res raznolika skupina, saj se disleksija pri vsakem kaže nekoliko drugače. Njihovi tako imenovani skriti darovi in primanjkljaji vplivajo na uspehe na področju izobraževanja, zaposlovanja in socialne vključenosti. Za uspešnost vsakega posameznika je pomembno, da se sam usmeri $v$ močna področja namesto $v$ primanjkljaje, ob tem pa ga mora podpirati tudi okolje, v katerem živi. Obstajajo številni miti o ljudeh z disleksijo, ki navajajo, da imajo slednji manjše intelektualne sposobnosti ali da so vsi izjemno nadarjeni, da so leni, da so bolniki, da z odraščanjem težave izginejo in podobno. V praksi so ti miti še vedno aktualni. Nekateri učitelji na vseh stopnjah izobraževanja posameznike z disleksijo še vedno zaznavajo kot manj sposobne, kot take, ki se premalo trudijo in dobivajo
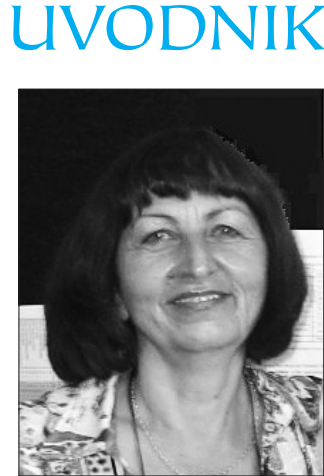

najnižje ocene, zaradi česar imajo mnogo manj možnosti za nadaljnje izobraževanje.

$V$ sekundarni mednarodni primerjalni analizi s področja pismenosti odraslih (IALS) (Magajna, Kavkler in Ortar-Križaj, Dyslexia, 2003, 9: 229-251) je bilo ugotovljeno, da so slovenske odrasle osebe, ki so v času izobraževanja imele slabše izobraževalne dosežke, opravile za dve do tri leta manj izobraževanja kot odrasle osebe s podobnimi težavami v drugih državah. Izobraževalna uspešnost naših udeležencev $v$ raziskavi je bila najbolj odvisna od podpore staršev. Še posebno obremenjujoča je ugotovitev, da so v času izobraževanja povsem izgubili motivacijo za učenje in se v obdobju odraslosti niso vključevali $v$ različne oblike vseživljenjskega izobraževanja, kar je sicer zaznati pri odraslih osebah $z$ disleksijo iz drugih držav. Spomine na negativne izobraževalne izkušnje lepo ilustrira zgodba gospoda Davida:

»Odpravil sem se $v$ trgovino $s$ šolskimi potrebščinami in kupil sinu pero. Ko sem pero prijel, da bi ga spravil, me je oblila vročica in dlani so bile v hipu vlažne. Čeprav je že dolgo od takrat, ko so me mučili s to napravo, in so današnja peresa tudi na pogled drugačna, je pero še vedno pero in tega se ne da izbrisati iz moje glave. Neskončno dolgi so bili popoldnevi, ko sem prepisoval razne tekste, največkrat so bili to šolski nareki, ki so imeli več rdečih popravkov, kot je bilo mojega modrega teksta. Seveda je bilo vse skupaj zabeljeno še s pacek nemarni ali lenoba ali še kaj hujšega." (Skriti primanjkljaji - skriti zakladi, 2007: 12.) 
Disleksija pa ne ovira posameznika le v procesu izobraževanja, ampak tudi pri drugih življenjsko pomembnih dejavnostih, denimo pri pripravi na vozniški izpit, kar je razvidno iz naslednjega opisa uspešne študentke z disleksijo:

»Pravi izziv zame predstavlja vozniški izpit. Nemogoče se mi zdi, da bi hkrati vozila, zraven pa opazila še vse prednostne trikotnike, omejitve, pešce in kolesarje. Enostavno je vsega preveč, skoncentriram se lahko le na eno stvar. $\mathrm{Na}$ začetku sem imela ogromne težave, vse je šlo narobe, razmišljala sem celo, da bi vse skupaj pustila in ostala pri kolesu. Težava je tudi $v$ tem, da tablo vidim, ne registriram pa, kaj na njej piše. Da sploh ne omenjam, da vsakič, ko inštruktor reče, da naj zavijem desno, jaz zavijem levo in obratno. (Razvoj inkluzivne vzgoje in izobraževanja, 2008: 7.)

Optimalen razvoj potencialov posameznikov $z$ disleksijo zato lahko dosežemo le z uvajanjem sistematičnih sprememb na vseh stopnjah izobraževanja. Na 23. konferenci ministrov za izobraževanje Sveta Evrope (2010) je bilo poudarjeno, da bo v prihodnosti velik izziv za pedagoško stroko upoštevanje raznolikih potreb raznolike učeče se populacije. Že leta 2007 pa je parlament EU sprejel izjavo o prenehanju diskriminacije in izključevanja oseb z različnimi specifičnimi učnimi težavami.

$V$ Sloveniji je od sprejetja Zakona o usmerjanju otrok s posebnimi potrebami (2000) iz leta $v$ leto identificiranih več učencev in dijakov z izrazitimi specifičnimi učnimi težavami oz. primanjkljaji na posameznih področjih učenja; $v$ vsej populaciji oseb s posebnimi potrebami je takih okrog 35 odstotkov (ZRSŠ, 2010). Žal pa številni učenci in dijaki s specifičnimi učnimi težavami niso deležni ustreznih oblik prilagajanja procesa poučevanja, ocenjevanja in specialnih strategij pomoči, kar je še posebno kritično $v$ srednjih šolah, zato kljub trudu niso uspešni.
Prav tako je v visokošolskih ustanovah vedno več študentov, ki imajo zaradi disleksije status študenta s posebnimi potrebami. Ocenjeno je, da je v populaciji študentov okrog tri odstotke takih z izrazitejšo disleksijo. Med 35 odstotki študentov, ki se vpišejo v visokošolsko ustanovo in študija ne dokončajo (NPVŠ, 2010), je velik delež takih z disleksijo in drugimi specifičnimi učnimi težavami. Za uspešen študij bi jim bilo treba bolj prilagoditi študijsko okolje in odstraniti ovire, ki jim preprečujejo, da bi ob vsem svojem intelektualnem potencialu študij uspešno dokončali.

Zmanjševanje osipa študentov $z$ disleksijo in drugimi specifičnimi učnimi težavami lahko dosežemo le s sistematično izpeljanim sistemskim pristopom. Kot zgled bi lahko služil model skrbi za študente z disleksijo, ki je bil izdelan v okviru mednarodnega projekta Tempus iSHEDS za študente z disleksijo. Projektna skupina Pedagoške fakultete Univerze v Ljubljani (Kavkler, Magajna, Košak Babuder, Zemljak, Janželj in Andrejčič) se je leta 2009 vključila v mednarodni projekt Tempus iSheds (2009-2010) »Prepoznavanje in podpora študentom z disleksijo $v$ visokošolskem izobraževanju« (Identification and Support in Higher Education For Dyslexic Students). Projekt je bil načrtovan z namenom spodbujanja prepoznavanja, podpore in pomoči, izobraževanja, uvajanja sodobne tehnologije ter načrtovanja ukrepov na področju univerzitetnega študija oseb z disleksijo. Raziskava, ki jo vodi prof. dr. Angela Fawcett z Univerze $v$ Swanseaju, vključuje države EU in zahodnega Balkana (Veliko Britanijo, Madžarsko, Romunijo, Slovenijo, Hrvaško, Bosno in Srbijo).

$V$ projektu Tempus iSHEDS smo preučevali različna področja, ki se navezujejo na odkrivanje študentov $z$ disleksijo ter spodbujanje podpore in pomoči zanje. Projektne skupine držav udeleženk smo pripravile gradiva in informacije, ki zajemajo različne vidike za različne dele sistema od pomoči študentu do 
namigov politiki, kar vse se povezuje z možnostmi za učinkovitejši študij študentov z disleksijo. Predlagane rešitve ne terjajo veliko dodatnih finančnih virov.

Analiza politik na področju skrbi za študente $z$ disleksijo $v$ vseh državah udeleženkah projekta Tempus iSHEDS bo služila kot izhodišče za spreminjanje politike v posamezni državi. Upamo, da bo tudi v slovenski visokošolski zakonodaji predvidena pravica do prilagoditve za vse študente s posebnimi potrebami in tako tudi za študente z disleksijo. V dokumentu NPVŠ (2010) je predvidena socialna in psihološka pomoč za študente, ki so rizični za osip, kar pa za študente $z$ disleksijo ni dovolj, saj potrebujejo uzakonjeno pravico do prilagoditve študijskega procesa vključno s prilagojenimi oblikami preverjanja znanja.

Vprašalnik in več testov za odkrivanje disleksije (iSHEDS Profiler), ki so bili prav tako izdelani v okviru projekta, omogočajo študentom, da sami identificirajo znamenja disleksije. Za celostno in poglobljeno diagnostično oceno, ki služi za pridobitev statusa študenta s posebnimi potrebami, pa je potrebna timska obravnava.

Zbrane so tudi številne informacije in dostopi do različnih brezplačnih programov podporne informacijsko-komunikacijske tehnologije, ki je $v$ veliko pomoč študentom z disleksijo, saj lahko nekateri s tehničnimi pripomočki kompenzirajo primanjkljaje in so uspešnejši pri študiju.

Zvočno opremljena e-gradiva, $v$ katerih so predstavljene različne strategije samopomoči pri reševanju študijskih stisk - od strategij premagovanja anksioznosti, študijskih veščin, strategij učinkovitejšega opravljanja izpitov do samozagovorništva itd. -, omogočajo študentom samostojnejši študij. BRAVO, društvo za pomoč otrokom in mladostnikom s specifičnimi učnimi težavami, je e-gradiva za študente izda- lo v knjigi z naslovom Disleksija - vodnik za samostojno učenje študentov in dijakov (2010).

Študenti se v visokošolski ustanovi najprej srečajo z administrativnimi delavci v referatu za študentske zadeve. Ker imajo ti študenti pogosto težave pri priklicu informacij, izpolnjevanju obrazcev itd., jim razumevajoč strokovni delavec $v$ referatu lahko močno omili številne stiske. Zato smo za administrativne delavce pripravili kratko informacijo o značilnostih in posebnih potrebah, ki jim bo v pomoč pri stiku s študenti z disleksijo.

Vedno bolj se $v$ visokošolskih ustanovah razvija tudi tutorski sistem pomoči in podpore študentom. Tutorji lahko učinkovito pomagajo študentom $z$ disleksijo, če poznajo značilnosti teh študentov in pristope, ki jim pomagajo učinkoviteje študirati, zato smo pripravili tudi e-gradivo za tutorje, da bodo laže pomagali študentom in svetovali ustrezne pristope tudi visokošolskim učiteljem. Vse strategije poučevanja, ki so nujne za uspešen študij študentov $z$ disleksijo, izboljšajo uspešnost študija tudi vsem drugim študentom. Vsa predstavljena gradiva so v jezikih sodelujočih držav objavljena na spletni strani www.isheds.eu.

Podoben sistemski model pomoči, ki smo ga pripravili za študente $z$ disleksijo, bi morali pripraviti in uresničevati za vse študente, $k i$ so rizični za osip.

\section{Dr. Marija Kavkler}

